\title{
MEETING THE CHALLENGES OF CANADIAN LEGAL HISTORY: THE ALBERTAN CONTRIBUTION
}

\author{
JOHN P.S. McLAREN
}

Canadian legal history has undergone a transformation during the past twenty-five years from a scholarly void to a lively branch of social and intellectual history. It is now recognized as an important area of research and speculation by legal academics, historians and people in a range of other humanities and social science disciplines. Courses in Canadian legal history are offered in most law schools and several history departments. This change has been brought about by the hard work and dedication of a small but energetic band of scholars. Albertan legal historians have played an important seminal role in this movement, in particular by researching and encouraging others to work on the legal history of the Northwest Territories and Prairie Provinces. This essay describes the growth of research into and the teaching of Canadian legal history in Alberta, and the special contributions of Wilbur Bowker, Louis Knafla and Rod Macleod to that endeavour. It concludes with several reflections on how interest in legal history in the Province might be further expanded.
L'histoire du droit canadien s'est transformée au cours des vingt-cing dernières années. $\dot{A}$ peu près inexistante il y a un quart de siècle, elle est devenue une branche dynamique de l'histoire sociale et intellectuelle. On reconnaît aujourd'hui qu'il s'agit d'un domaine important de recherche et de spéculations pour les juristes, les historiens et les spécialistes oeuvrant dans différentes disciplines des sciences humaines et sociales. La plupart des écoles de droit et plusieurs départements d'histoire offrent désormais des cours d'histoire du droit. Cette évolution est due aux efforts soutenus et au dévouement d'un petit groupe d'universitaires énergiques. Les historiens du droit albertains ont joué un rôle important dans ce mouvement, en particulier en effectuant et en encourageant des travaux de recherche sur l'histoire des Territoires du Nord-Ouest et des provinces des Prairies. Le présent article décrit l'évolution de la recherche et de l'enseignement portant sur l'histoire du droit canadien en Alberta, et décrit les contributions de Wilbur Bowker, de Louis Knafla et de Rod Macleod à cet égard. En conclusion, il propose plusieurs réflexions sur la façon de promouvoir la discipline dans la province.

TABLE OF CONTENTS

I. INTRODUCTION $\ldots \ldots \ldots \ldots \ldots \ldots \ldots \ldots \ldots \ldots \ldots \ldots$

II. THE DAWNING OF CANADIAN LEGAL

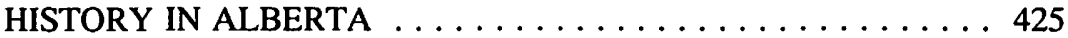

III. RISING TO THE CHALLENGE OF CANADIAN

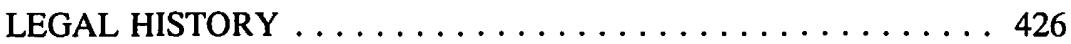

IV. CONCLUSION - THE CONTINUING CHALLENGE $\ldots \ldots \ldots 433$

\section{INTRODUCTION}

Before 1966, it would have been difficult to make the case that there was a definable body of Canadian legal history, let alone anything which approximated scholarly traditions in the social and intellectual history of Canadian law. There were, admittedly, a few oases in the legal historical desert. Through the iconoclasm and daunting effort of William Renwick Riddell, Justice of the Ontario High Court from 1906 to 1945, valuable records

Former Dean, Faculty of Law, University of Calgary. Now Lansdowne Professor of Law, University of Victoria. 
of the legal history of Upper Canada and Ontario were preserved and edited, and histories of both the courts and legal profession were written. ${ }^{1}$ In Quebec, a tradition of legal historical scholarship developed late in the nineteenth century, extending into the late 1930s. Legal scholars and historians examined the outlines of legal development in New France and Quebec, as well as specific aspects of the institutional and substantive law of the colony and province. ${ }^{2}$ In the main, however, Canadian scholars seemed content to assume that the only legal history which had any claim to attention was that of England or France.

Since 1966, legal history has developed into a vigorous sub-discipline of Canadian history with close and overlapping linkages with elements of the social, intellectual and economic history of the country. This blossoming of legal history stems from the dedicated work of a relatively small but highly energetic group of law teachers and historians who have recognized the importance of an understanding of the history of law, legal institutions and legal theory and ideology in promoting a broader appreciation of the Canadian experience. Their ideas have been put into practice in the classroom and published word. ${ }^{3}$ The founding of the Osgoode Society by members of the Law Society of Upper Canada has also benefitted legal history by promoting scholarship in this field. In its short existence, the Society has built up an impressive record of achievement, publishing a series of important monographs and collections of essays and encouraging further work in the field through its fellowship programme. A more recent focus for Canadian legal historical research is the Supreme Court of Canada Historical Society, dedicated to opening up the record and socio-political significance of the country's highest court.

In the story of the blooming of Canadian legal history, it is particularly important to point to the role of Albertan scholars. They have been involved in charting important areas of legal history (especially but not exclusively that of the West), assisting future research by recording and rationalizing a wealth of primary materials, and encouraging and supervising graduate work in the field. It is, I would suggest, not too much to claim

1 On the life and times of Justice Riddell, see H.B. Neary, "William Renwick Riddell: Judge, Ontario Publicist and Man of Letters" (1977) 11 L.S.U.C. Gazette 144. His career and prodigious scholarly output as an historian and man of letters are dealt with at 161-171. Riddell's work in legal history was largely descriptive. He served as a trial judge from 1906 to 1926 and then on the Court of Appeal until his death in 1945.

A. Morel, "Canadian Legal History - Retrospect and Prospect" (1983) 21 Osgoode Hall L.J. 159. Among this group rank Dick Risk (Law, University of Toronto); Graham Parker and Douglas Hay (Law/History, York University); André Morel (Law, Université de Montréal); David Flaherty (History, University of Western Ontario); Connie Backhouse (Law, University of Western Ontario); Louis Knafla (History, University of Calgary); André Lachance (History, Université de Sherbrooke); Rod Macleod (History, University of Alberta); Jean-Marie Fecteau (History, UQAM); Hamar Foster (Law, University of Victoria); Blaine Baker (Law, McGill University); Barry Wright (Law, Carleton University); Wes Pue (Law, University of British Columbia); Phil Girard (Law, Dalhousie University); Jim Phillips (Law, University of Toronto); David Bell (Law, University of New Brunswick); Dale Gibson (Law, University of Alberta); DeLloyd Guth (Law, University of British Columbia); Chris Levy (Law, University of Calgary); Howard McConnell (Law, University of Saskatchewan). 
that Albertans have been in the forefront in the teaching and research of Canadian legal history since the mid-1960s.

\section{THE DAWNING OF CANADIAN LEGAL HISTORY IN ALBERTA}

In Alberta, the seeds of interest in Canadian legal history were sown as early as the 1930s. Two small but important patches of ground were tilled by the time the sub-discipline began to put up shoots in the 1960s. In the 1934 inaugural number of the Alberta Law Quarterly, the Chief Justice of the Province, Horace Harvey - whose career on the Bench straddled an amazing 44 years stretching back to the territorial period wrote a short, but for the time detailed and learned description of the early administration of justice in the Northwest. ${ }^{4}$ After his death in 1949, Harvey was himself the subject of an extended biographical article in a 1954 edition of the Canadian Bar Review. This full, careful and engaging description of augustan Harvey's life and contribution to the law (a far cry from the limited and amateurish pieces which had passed for judicial biography to that date), was penned by Wilbur Bowker, former Dean of the University of Alberta Faculty of Law. ${ }^{5}$ Dean Bowker, who combines an encyclopaedic knowledge of the law and its development with an infectious enthusiasm for history and great clarity of expression, could well be described as the father of Alberta legal history on the basis of this piece of scholarship alone. The article, which stood for a number of years as a tantalizing but lone model of what good judicial biography could be, reflected Professor Bowker's strong belief that, alongside a natural interest in the history of English law, Canadian lawyers should begin to recognize and investigate their own legal record and what it might reveal of a rich and distinctive legal culture. The evident pride which the writer exhibits in the first pages of the article for the Chief Justice's remarkable stand against subversion of the rule of law by the federal Government and military authorities during the conscription crisis of World War I, leaves the reader in no doubt about his belief that the life of Horace Harvey is a story to be told and cherished. ${ }^{6}$

At the time Dean Bowker wrote his article, the teaching of legal history in the Common Law schools of Canada was limited almost exclusively to the evolution of English law, typically in variations of a legal version of 1066 and All That. ${ }^{7}$ His commitment to exposing the Canadian legal record, especially that in the West, was shared by another Western Canadian legal scholar, Professor D. Colwyn Williams of the College of Law, University of Saskatchewan. Colwyn Williams, a personable and flamboyant Welshman, taught the first year legal history course in Saskatoon. He was convinced that students needed to understand how the Common Law - that seemingly remote body of jurisprudence which now affected their lives and which they aspired to practise - had been transplanted from the misty marshes and fields of England to the vast, wind blown expanses of the Canadian Plains. Professor Williams gave concrete expression to his beliefs in a series of articles in the Saskatchewan Bar Review. These

H. Harvey, "The Early Administration of Justice in the North West" (1934) 1 Alta. L.Q. 1.

W. Bowker, "The Honourable Horace Harvey, Chief Justice of Alberta" (1954) 32 Can. Bar Rev. 933, 1118.

lbid. at 934. The case in question was Re Lewis (1918), 13 Alta. L.R. 423 (A.D.).

W.C. Sellar \& R.J. Yeatman, (London: Methuen, 1930). 
articles relied heavily on legislative material and comprehensively set out the basic facts of the dawn and spread of English law on the Prairies between 1670, with the arrival of the Company of Adventurers on the shores of Hudson Bay, and 1905, the date of the establishment of the Provinces of Alberta and Saskatchewan. ${ }^{8}$

\section{RISING TO THE CHALLENGE OF CANADIAN LEGAL HISTORY}

In effect, Professors Bowker and Williams presented a challenge to other scholars to take the history of Western Canada seriously, and to extend the research agenda. Happily, two extremely able legal historians from the Departments of History at the University of Calgary and the University of Alberta respectively, were willing and able to oblige.

Dr. Louis Knafla, educated in the United States, went to the University of Alberta, Calgary campus in 1965 - a year before its demise and conversion into the University of Calgary. A specialist in the legal history of Tudor and Jacobean England, Louis Knafla was a relative rarity in Canadian history departments: a legal historian with a mission to teach and excite interest in his field. Although he has maintained an abiding interest in early modern English legal history, ${ }^{9}$ he has diversified his interests over the years and made a conscious commitment to research and teach Canadian legal history. This effort has included work on the bibliography and substance of Canadian criminal law and justice, as well as the development of legal culture in the Canadian West.

Four years after Knafla's arrival in Calgary, Roderick Macleod, an Albertan, returned to his alma mater to teach history. Macleod was already well versed in the legal history of Western Canada, specializing in the history of the North West Mounted Police and their enforcement of law on the Prairies from 1874. In his research and teaching at the University of Alberta, he has continued to expand this work, and in the process further develop an understanding of the social, political and legal significance of the force in establishing law and order on the Prairies. At the same time, he has shown an interest in the broader political history of Western Canada and in the history of Canadian criminal law.

Through the individual and combined efforts of these scholars, and their encouragement of other scholars and students, the field of Canadian legal history, and especially the legal history of the Prairie West, has flourished in Alberta. Knafla was quick to recognize the importance of taking the initiative in sowing the seeds of interest in Canadian legal history with both colleagues and history students. He also recognized that as far as research into Western legal history was concerned (a field which would have a natural attraction for honours and graduate students based in Alberta), work needed to be done to search out,

* D. Colwyn Williams, "The Dawn of Law on the Prairies" (1962) 27 Sask. Bar Rev. 126, (1963) 28 Sask. Bar Rev. 17, 63; "Law and Institutions in the North West Territories (1869-1905)" (1963) 28 Sask. Bar Rev. 109, (1964) 29 Sask. Bar Rev. 51, 83, (1965) 30 Sask. Bar Rev. 51, (1966) 31 Sask. Bar Rev. 1, 137, (1968) 33 Sask. Bar Rev. 145.

Among his many publications on early modern English legal history is L. Knafla, Law and Politics in Jacobean England: The Tracts of Lord Chancellor Ellesmere (Cambridge: Cambridge University Press, 1977). 
rationalize and record the important primary source material which researchers would need to consult.

During the 1970s, Knafla was a leading participant in the establishment and work of the Canadian Society of Legal History, editing its newsletter from 1971 to $1975 .{ }^{10}$ In 1977, in the form of Proceedings of the Society, he edited what must have been the first book of essays on legal history produced in Canada. ${ }^{11}$ Along with three papers presented at a joint session of the Society and the Canadian Historical Association were two which had started life as papers by his graduate students, Terry Chapman and Tom Thorner, on Western Canadian legal historical themes. ${ }^{12}$ This was to be but the first sign of Lou Knafla's strong belief in assisting students doing advanced work in legal history to get into print and in the process to develop confidence in sharing their research, findings and conclusions. Although the Society did not survive the decade (its demise perhaps reflecting the small number of people working actively in the field), Knafla's interest in expanding the field of Canadian legal history remained undaunted.

The opening of the Faculty of Law at the University of Calgary in 1976 provided Knafla with the opportunity to engage in collaborative work, particularly in the classroom, with an avid enthusiast of legal history, Professor Chris Levy. In their jointly taught course on the historical foundations of the common law, the duo were to excite considerable interest in legal history among undergraduates, inducing some to go on to graduate studies in the field. ${ }^{13}$

Together with David Bercuson, a colleague specializing in social and labour history, Knafla, as part of the University of Calgary Studies in History, produced another pioneer collection of essays in 1979. These focused for the first time on the history of law and society in Canada. ${ }^{14}$ Included along with the work of established scholars such as Michael Cross, ${ }^{15}$ Murray Fraser, ${ }^{16}$ Pierre Patenaude ${ }^{17}$ and Chris Levy ${ }^{18}$ were again essays by Chapman and Thorner investigating the social context of the criminal law in Western Canada. ${ }^{19}$

Canadian Society of Legal History Newsletter, nos. 1-4, 1971-1975.

$1 \quad$ L. Knafla, ed., Canadian Society for Legal History, Proceedings 1977 (Toronto: York University Law Library, 1977).

T. Chapman, "Drug Usage and the Victoria Daily Colonist; The Opium Smokers of Western Canada" in Knafla, ed., ibid. 60; T. Thorner, "Sources for Legal History in the Archives of Saskatchewan and Alberta", ibid. 76.

The objectives and substance of the course are described in L. Knafla \& C. Levy, "The Historical Foundations of the Common Law" in C. Hunt, ed., Legal Education at Calgary ... Beyond Socrates (Calgary: Faculty of Law, 1977) 21.

D. Bercuson \& L. Knafla, eds., Law and Society in Canada in Historical Perspective (Calgary: University of Calgary Press, 1979).

M.S. Cross, "Violence and Authority: The Case of Bytown" in Bercuson \& Knafla, eds., ibid. 5.

F.M. Fraser, "Child Abuse in Nova Scotia", ibid. 117.

P. Patenaude, "The Evolution of the Right of Privacy in Quebec", ibid. 45.

J.C. Levy, "The Poor Laws in Early Upper Canada", ibid. 23.

T. Chapman, "The Anti-Drug Crusade in Western Canada, 1885-1925", ibid. 89; T. Thorner, "The Incidence of Crime in Southern Alberta", ibid. 53 [hereinafter "Incidence of Crime"]. 
Knafla has for long had an interest in investigating the comparative aspects of the history of crime and criminal justice, and putting the Canadian record into a broader, international context. His association with scholars with a similar bent in both Europe and elsewhere in Canada inspired him to mount a conference on Crime and Criminal Justice in Europe and Canada at the University of Calgary in June 1979. Together with the Calgary Institute for the Humanities, he published the proceedings in $1981 .^{20}$ Within the collection are seminal essays on the history of Canadian crime and criminal justice, including pieces by seasoned scholars such as Douglas Hay, ${ }^{21}$ André Lachance ${ }^{22}$ and Simon Verdun-Jones. ${ }^{23}$ Characteristically, the work of three graduate students who presented papers to the conference was also published. ${ }^{24}$

The strong commitment which Louis Knafla has to comparative scholarship in crime and criminal justice is also evident in his editing of Criminal Justice History: An International Annual. Here again he has made an important contribution to Canadian legal historiography. Along with articles from other jurisdictions, he has published a number of important studies of the Canadian criminal justice system and culture. ${ }^{25}$

From 1978 to date, a large part of Louis Knafla's energies in the field of Canadian legal history has been directed to the preservation of primary sources, and in particular court records. With the assistance of Rod Macleod and the moral support of the Faculty of Law at the University of Calgary, he founded and coordinated the Alberta Legal History Project. ${ }^{26}$ Funded in large part by the Alberta Law Foundation, the objective of the project has been to preserve in one form or another all of the extant records generated in the Province's court houses in both the territorial and provincial periods. In conjunction

L. Knafla, ed., Crime and Criminal Justice in Europe and Canada (Waterloo, Ont.: Wilfrid Laurier University Press, 1981).

D. Hay, "The Meanings of the Criminal Law in Quebec, 1764-1774" ibid. 77.

A. Lachance, "Women and Crime in the Early Eighteenth Century, 1712-1759" ibid. 157.

S.N. Verdun-Jones, "'Not Guilty by Reason of Insanity': The Historical Roots of the Canadian Insanity Defence, 1843-1920", ibid. 179.

T. Chapman, "The Measurement of Crime in Nineteenth-Century Canada: Some Methodological and Philosophical Problems", ibid. 147; T. Thorner \& N. Watson, "Patterns of Prairie Crime: Calgary, 1875-1939", ibid. 219 [hereinafter "Patterns"].

S.N. Verdun-Jones and R. Smandych, "Catch-22 in the Nineteenth Century: The Evolution of Confinement for the Criminally Insane in Canada, 1840-1900" (1981) 2 Crim. Just. Hist. 85; T. Chapman, "'An Oscar Wilde Type': The Abominable Crime of Buggery in Western Canada, 1890-1920" (1983) 4 Crim. Just. Hist. 97; J. Woods, "Criminal Justice History in Canada: A Brief Survey of Work in Progress" (1983) 4 Crim. Just. Hist. 119; F.M. Greenwood, "The Chartrand Murder Trial: Rebellion and Repression in Lower Canada, 1837-1839" (1984) 5 Crim. Just. Hist. 129; J. Levy, "Legal History and the History of the Criminal Law" (1984) 5 Crim. Just. Hist. 171; A. Brannigan, "Mystification of the Innocents: Crime Comics and Delinquency in Canada, 1931-1949" (1986) 7 Crim. Just. Hist. 111; J. McLaren, "White Slavers: The Reform of Canada's Prostitution Laws and Patterns of Enforcement, 1900-1920" (1987) 8 Crim. Just. Hist. 53 [hereinafter "White Slavers"]; H. Foster, "Sins Against the Great Spirit: The Law, the Hudson's Bay Company and the MacKenzie River Murders, 1835-1839" (1989) 10 Crim. Just. Hist. 23; J.B. Wright, "The Ideological Dimensions of Law in Upper Canada: The Treason Proceedings of 1838" (1989) 10 Crim. Just. Hist. 131; P. Sibenik, "Under the Lamplight: Criminal Justice History in Canada" (1989) 10 Crim. Just. Hist. 213 [hereinafter "Under the Lamplight"].

For a description of the project, see G. Parker, "Alberta Legal History Project" (1981) 2 Now and Then 3. 
with the Provincial Archives of Alberta, which had been converting large portions of the files of the Attorney General's Department (including court records) into microfilm, a comprehensive list was developed for all entries from the several judicial districts (covering civil and criminal matters), and sample selections of case files were maintained in hard copy form. In the process, Dr. Knafla and his research assistants were able to preserve important material, especially that formerly stored in small rural court houses. What has emerged is a well organized and immensely rich data base for researchers interested in plumbing the depths of regional and local legal history in the North West Territories and Alberta. The product is already evident in the work of several graduate students who have worked under the supervision of Drs. Knafla and Macleod. ${ }^{27}$

The growth of interest in the legal history of Western Canada which had been sparked in large part by both Knafla and Macleod was sufficient to persuade the former that it was time to bring together scholars working in the field to share the product of their labours and to encourage further effort. Together with the author and the Calgary Institute for the Humanities, Knafla organized the Conference on Western Canadian Legal History in April 1984. The programme focused on a distinctive series of themes which were emerging within the broader field of Western legal history (i.e. the control of morality, aboriginal rights, resource development, and frontier government and justice). A compelling feature of the event, one generally evident in Canadian legal historiography to date, was the diversity of disciplines represented (including not only law and history, but also political science and criminology) and the theoretical underpinnings of the work presented. An important outcome of the conference for which Louis Knafla must take full credit was the publication of a book of essays in 1986 on Western Canadian Legal History, Law and Justice in A New Land. ${ }^{28}$ In tune with his earlier work, Knafla included pieces by two graduate students: Peter Sibenik, who had worked under his supervision; and Elizabeth Langdon, a law student with graduate experience in social and intellectual history. ${ }^{29}$ The book also included the first historiography and bibliography of the legal history of the West. ${ }^{30}$ It quickly became the text and source book for legal history courses concentrating on this region of Canada. ${ }^{31}$

It has also provided the basis for collaboration between Dr. Knafla and Dr. De Lloyd Guth of the Faculty of Law, University of British Columbia on a project for the preservation and rationalization of legal historical records for the four western provinces and the territories. L. Knafla, ed., Law and Justice in a New Land: Essays in Western Canadian Legal History (Calgary: Carswell Ltd., 1986) [hereinafter Law and Justice].

P. Sibenik, "Points of Departure: Urban Relief in Alberta, 1930-1937" ibid. 313 [hereinafter "Points of Departure"]; E. Langdon, "Female Crime in Calgary, 1914-1941", ibid. 293.

L. Knafla, "From Oral to Written Memory: The Common Law Tradition in Western Canada", ibid. 31; J. Dickin McGinnis, "Bibliography of the Legal History of Western Canada", ibid. 333. Other Albertan scholars who contributed were: N. Bankes, "Indian Resource Rights and Constitutional Enactments in Western Canada, 1871-1930", ibid. 129; W. Bowker, "The Sproule Case: Bloodshed at Kootenay Lake, 1885", ibid. 233 [hereinafter "Bloodshed at Kootenay Lake"]; T. Flanagan, "From Indian Title to Aboriginal Rights", ibid. at 81 [hereinafter "From Indian Title"]; T. Chapman, "Male Homosexuality: Legal Restraints and Social Altitudes in Western Canada, 1890-1920", ibid. 277.

31 Recently Knafla has begun investigating the role of lawyers in the West - see L. Knafla, "Richard 'Bonfire' Bennett: The Legal Practice of a Prairie Corporate Lawyer, 1898-1913" in C. Wilton, ed., Essays in the History of Canadian Law (Beyond the Law: Lawyers and Business in Canada, 1830 to 1930), vol. IV (Toronto: Osgoode Society, 1990) 320. 
Although he has been supportive of and to some extent involved in Knafla's initiatives, Rod Macleod's role in the stimulation of interest in Canadian legal history has been less one of organizing the process of acquiring knowledge and insight, and more the provision of inspiration at a personal level through the example he has shown in his own research agenda and in the supervision of graduate students. As indicated earlier, Macleod arrived at the University of Alberta as a specialist in the history of the N.W.M.P. Since 1969, he has published an impressive body of scholarship on the force which has established him as the expert in the field. His book, The North West Police and Law Enforcement 1873-1905, published in 1975, is the leading history of this remarkable institution and its vital role in the process of opening up the Canadian Prairies in an orderly manner. ${ }^{32} \mathrm{He}$ has also written a series of articles and essays on more specific features of the record of the mounted police. ${ }^{33}$ The work Macleod has done on the Mounties has led him into research on the general political and military history of the Prairies. Forming part of that body of scholarship is an authoritative monograph with Bob Beal on the 1885 North West Rebellion. ${ }^{34}$ It has also been important to Macleod that, in addition to disseminating the results of his own historical scholarship, he expose contemporary material relating to the establishment of order in the West. This he has done by editing diaries relating to the Rebellion, including an extensive autobiography of a Victorian soldier who saw service in that operation. ${ }^{35}$

In the course of time Rod Macleod has developed broader interests in the history of criminal justice and law in Canada. In addition to writing on the evolution of Canada's criminal law during the decade succeeding the enactment of the 1892 Criminal Code, ${ }^{36}$ he has recently edited a primer on the history of criminal justice, which incorporates some of the best literature to date on the topic from all quarters of the country. ${ }^{37}$ The anthology is helpfully constructed around four general themes: criminals and criminality; the police and enforcement; courts and the criminal law; and prisons, punishment and rehabilitation.

In common with Knafla, Macleod has encouraged graduate students to work through their interest in Canadian legal history and to publish the results. The most notable

R. Macleod, The North West Mounted Police and Law Enforcement 1873-1905 (Toronto: University of Toronto Press, 1975).

33 "The Mounted Police and Politics" in H. Dempsey, ed., Men in Scarlet (Toronto: McClelland \& Stewart, 1974) 95; "The Problem of Law and Order in the Canadian West 1870-1905" in L.H. Thomas, ed., The Prairie West to 1905: A Canadian Sourcebook (Toronto: Oxford University Press, 1975) 132; "Canadianizing the West: The North West Mounted Police as Agents of the National Policy, 1873-1905" in L.H. Thomas, ed., Essays on Western History (Edmonton: University of Alberta Press, 1976) 101; The North West Mounted Police 1873-1919 (Canadian Historical Association, Historical Booklet no. 31, 1978).

R. Macleod \& R. Beal, Prairie Fire: The 1885 North West Rebellion (Edmonton: Hurtig, 1984).

R. Macleod, ed., Reminiscences of a Bungle by One of the Bunglers and Two Other North West Rebellion Diaries (Edmonton: University of Alberta Press, 1983); R. Macleod, ed., Gunner Jingo's Jubilee (Edmonton: University of Alberta Press, 1988).

R. Macleod, "The Shaping of Canadian Criminal Law, 1892-1902" (1978) 31 Can. Hist. Assoc. Papers.

R. Macleod, ed., Lawful Authority: Readings on the History of Criminal Justice in Canada (Toronto: Copp, Clark, Pittman Lid., 1988). 
example to date is the work of Desmond Brown on the history of the Canadian Criminal Code. ${ }^{38}$

Both Knafla and Macleod have been responsible for inspiring a small but able and enthusiastic group of Canadian, and in particular Western Canadian, legal historians to teach, research and publish in the area. These individuals are teaching in university or college history departments or are engaged in law reform work, and continue to be active in scholarship. Their published works include studies of: the genesis of the Canadian Criminal Code ${ }^{39}$ specific criminal trials; ${ }^{40}$ law, sex and gender relations in Western Canada; ${ }^{41}$ the proscription of drugs in the Canadian West; ${ }^{42}$ film censorship in Lethbridge; ${ }^{43}$ the evolution of the legal profession and legal education in Alberta and Manitoba; ${ }^{44}$ urban relief in depression-era Alberta; ${ }^{45}$ crime and criminal justice in Alberta; ${ }^{46}$ the MacMillan v. Brownlee seduction case; ${ }^{47}$ and law and the system of justice in the Red Deer District. ${ }^{48}$ What is striking about most of this work is the extent to which it draws upon regional, provincial and local records. It suggests strongly the importance of the analysis of those materials to an understanding of the contingency of, and variations in legal culture in, Canada and the extent to which the law and legal institutions have an impact on the day to day lives of the population.

It would be wrong to suggest that Knafla and Macleod have exclusively occupied the field of Canadian legal history in Alberta in recent decades. Recognition must go in

D. Brown, The Genesis of the Canadian Criminal Code of 1892 (Toronto: Osgoode Society, 1989). Ibid.; D. Brown, "Unpredictable and Uncertain: Criminal Law in the Canadian Northwest Before 1886" (1979) 17 Alta. L. Rev. 497.

D. Brown, "The Meaning of Treason, 1885" (1975) 28 Sask. Hist. 65; D. Brown, "The Craftsmanship of Bias: Sedition and the Winnipeg Strike Trial 1919" (1984) 14 Man. L.J. 1.

Chapman, supra notes 25, 30; T. Chapman, "Early Eugenics Movement in Western Canada" (1977) 25 Alta. Hist. 9; T. Chapman, "Women, Sex and Marriage in Western Canada, 1890-1920" (1985) 33 Alta. Hist. 1; T. Chapman, "Sex Crimes in the West, 1890-1920" (1987) 35 Alta. Hist. 6; T. Chapman, "Till Death Do Us Part': Wife Beating in Alberta, 1905-1920" (1988) 36 Alta. Hist. 13. Chapman did an M.A. under the supervision of Knafla and a Ph.D. under Macleod's supervision. Chapman, supra notes 12, 19; T. Chapman, "Drug Use in Western Canada" (1976) 24 Alta. Hist. 18. T. Chapman, "Film Censorship in Lethbridge 1918-1920" (1985) 33 Alta. Hist. 1.

"Under the Lamplight", supra note 25; P. Sibenik, "'The Black Sheep': The Disciplining of Territorial and Alberta Lawyers, 1885-1928" (1988) 3 Can. J.L. \& S. 109; P. Sibenik, "Door Keepers: Legal Education in the Territories and Alberta, 1885-1928" (1990) 13 Dalhousie L.J. 421; R. Willie, "It is Every Man for Himself: Winnipeg Lawyers and the Law Business, 1870 to 1903" in Wilton, ed., supra note 31, at 263. Sibenik did an M.A. with Knafla, Willie a Ph.D. with Macleod.

"Points of Departure", supra note 29.

"Incidence of Crime", supra note 19; "Patterns", supra note 24; T. Thorner, "The Not So Peaceable Kingdom - Crime and Criminal Justice in Frontier Calgary" in A. Rasporich \& H. Klassen, eds., Frontier Calgary Town, City \& Region 1875.1914 (Calgary: McClelland \& Stewart West, 1975); T. Thorner \& N. Watson, "Keeper of the King's Peace: Colonel G.E. Sanders and the Calgary Police Magistrate's Court, 1911-1932" (1984) 12 Urb. Hist. Rev. 45. Both Thorner and Watson did M.A. degrees with Knafla.

[1940] 3 D.L.R. 355; T. Thorner \& N. Reddekopp, "A Question of Seduction: the Case of MacMillan v. Brownlee" (1982) 20 Alta L. Rev. 447.

J. Swainger, "Ideology, Social Capital and Entrepreneurship: Lawyers and Business in Red Deer, Alberta, 1900-1920" in Wilton, supra note 31 at 377. Swainger was supervised in his M.A. by Knafla. 
particular to Wilbur Bowker who has continued to contribute valuable insights to our knowledge of the development of law and justice in the West. In his biographical essay on the life and times of George Steer Q.C., he has shifted focus from the Bench to a distinguished Albertan practitioner. ${ }^{49}$ As with Chief Justice Harvey, his treatment of Steer, whose career loomed so large in the short history of the provincial bar, is both detailed and sympathetic. Dean Bowker's analysis of the role of the stipendiary magistrates and the early Supreme Court justices of the territorial period exposes the remarkable contribution of these men to establishing an ordered and respected system of justice on the Prairies, and in taking and moulding the Common Law so that it fits local circumstances. ${ }^{50}$ Furthermore, it provides interesting insights into the personalities of the men in question and their perception of their role as judges on the frontier. In his study of the Sproule murder trial from the Kootenays in 1885, Professor Bowker opened up the record of an important but neglected incident in the history of Western Canadian frontier justice. There, he noted the high emotions generated by mining activity and claims, and stressed both the practical and symbolic impact of British notions of law, order and justice even in the remotest corners of the region. ${ }^{51}$

In the field of the social history of Canadian law, the contribution of Dr. Janice Dickin McGinnis, Director of the Law and Society Programme in the Faculty of General Studies at the University of Calgary, has also been important. Originally a historian of epidemics and public health regulation, Dickin McGinnis has turned her attention in recent years to a range of legal historical issues. In some, she has combined her previous interest in the history of public health regulation with concerns about the use of law in a highly instrumental manner to create a "moral community" both in the past and in the present. Thus, in a recent article she examines closely and critically the parallels between the socio-legal discourse associated with fears of the adverse effects of venereal disease at the beginning of the present century and that related to anxieties about the social impact of the AIDS epidemic today. ${ }^{52} \mathrm{Her}$ concern with the translation of moral arguments into pressure for reform of the law, especially the criminal law, is the focus of a thought provoking article on the history of the attempted proscription of crime comics in Canada, and the relevance of that experience to the contemporary debate on pornography ${ }^{53} \mathrm{Dr}$. Dickin McGinnis has also struck out in directions unrelated to disease and morality, in particular with incisive biographical work on one of Calgary's longest serving solicitors, Frank Burnet. ${ }^{54}$ She is currently engaged in a long term project using the Western Weekly Reports as a vehicle for tracking the involvement of women and their interests as the subjects of litigation, and in turn, for exploring what those episodes reveal of the

W. Bowker, "Fifty-five years at the Alberta Bar: George Hobson Steer, Q.C." (1982) 20 Alta. L. Rev. 242.

W. Bowker, "Stipendiary Magistrates and Supreme Court of the North-West Territories, 1876-1907" (1988) 26 Alta. L. Rev. 245.

"Bloodshed at Kootenay Lake", supra note 30.

J. Dickin McGinnis, "Law and the Regulation of Lust: Regulating Syphilis and Aids" (1990) 22 Ottawa L. Rev. 49.

J. Dickin McGinnis, "Bogeymen and the Law: Crime Comics and Pornography" (1988) 20 Ottawa L. Rev. 3.

J. Dickin McGinnis, "When Lawyers Were Scholars, Frank L. Burnet" in M. Foran \& S. Jamieson, eds., Citymakers: Calgarians after the Frontier (Calgary: Historical Society of Alberta, 1987) 131. 
political, social and economic realities of female life and work in Western Canadian society. ${ }^{55}$

I have said already that Canadian legal history has attracted interest in disciplines other than law and history. Elements of Western legal history are also present in the work of the University of Calgary political scientist, Thomas Flanagan. Associated closely with his extensive work on the life and times of Louis Riel are analyses of his trial and its legality, as well as an assessment of the subsequent examination of whether Riel was insane or not. Flanagan concludes that in terms of the legal rules, processes and values of the time, there was in fact no miscarriage of justice, although the Dominion government was guilty of manipulation of the process and bad faith in its handling of the insanity issue. ${ }^{56} \mathrm{He}$ has also written on the history of the more pervasive issue of Metis and Native land rights. The work which proceeds from the view that there is no denying the legitimacy of European sovereignty over Canada, and that recognition of aboriginal rights is purely a matter of "grace" on the part of white governments, is controversial. The research is, however, both thorough and reflective and makes a plausible argument for the legalistic interpretation..$^{57}$

\section{CONCLUSION - THE CONTINUING CHALLENGE}

It should be apparent from this analysis that the contribution of Albertan scholars to the opening up of interest and work in Canadian legal history has been significant, even singular. By dint of the efforts of Bowker, Knafla and Macleod in particular, the sub-discipline has achieved both academic credibility among other scholars and students, and an ongoing life of its own. By a combination of infectious enthusiasm, shrewd organizational planning and the active encouragement of graduate students, these individuals have created the conditions in which the cause of Canadian, and especially Western Canadian, legal history may be expected to prosper. Most importantly, there is now a cadre of young scholars and teachers with a commitment to legal historical scholarship which will continue to grow as new graduate students become involved in this type of work.

There is, of course, much work still to be done and significant gaps in our knowledge to be filled, even within the confines of the legal history of Alberta. Some areas have been by and large untouched, while valuable pioneer work has been done on others which

J. Dickin McGinnis, "A Place for Legal Case Reports in the Historiography of Women: An Analysis Utilizing the Western Weekly Reports," Paper to "Law for the Elephant, Law for the Beaver," Transboundary Conference on the Legal History of the West and North-West of North America,

- 21-23 February 1991, University of Victoria.

56 T. Flanagan \& N. Watson, "The Riel Trial Revisited" (1981) 34 Sask. Hist. 57; T. Flanagan, "The Riel 'Lunacy Commission': The Report of Dr. Valade" (1976) 46 Rev. de U. Ottawa 108.

57 "From Indian Title", supra note 30; T. Flanagan, "The Case against Metis Aboriginal Rights" (1983) 9 Can. Pub. Pol. 314; T. Flanagan, "The Metis and Aboriginal Rights: Some Historical and Contemplating Problems" in M. Boldt, J. Long \& L. Little Bear, eds., Aboriginal Rights in Canada (Toronto: University of Toronto Press, 1985) 230; T. Flanagan, "Francisco Vitoria and the Meaning of Aboriginal Rights" (1988) 95 Queen's Q. 421. 
provides a basis for further study and elaboration. ${ }^{58}$ Although various theoretical insights have been brought to bear in the legal historical work already done in Alberta, it is too early to discern any particular trend. This is all to the good in the sense that no one has been discouraged from working in the field because of some ideological orthodoxy or the frustration caused by partisan struggles over what may or may not be acceptable. ${ }^{59}$ However, there is certainly room for work which is rooted in particular theoretical and ideological traditions. ${ }^{60}$

The encouragement of further research in the field of legal history in Alberta is made easier by the first rate work which has been done on rationalizing archival sources and providing ready access to them in the Province. Legal historical scholarship in Alberta is assisted greatly by the presence of a provincial archives system, including both the Provincial Archives in Edmonton and the Glenbow Archives in Calgary. These contain a wealth of material relating to the legal heritage of the Prairies, and possess staff and systems which are particularly sensitive and responsive to the needs of legal historical researchers. Recently, the Law Society of Alberta has recognized the importance of preserving and rationalizing its own collection of archival materials, as well as those generated by law firms. Through the collaboration of the Society and the Provincial Archives an active Legal Archives Society has been established under the able guidance of Graham Price and Rick Klumpenhouwer to coordinate the work of saving and organizing records and artifacts. ${ }^{61}$

Happily, those who have contributed so much to this positive state of affairs are still actively working in the field. It is important that, both by the individual effort of others and strong institutional commitment to continuing and expanding activity, excellence in the field is maintained. The Universities, the legal profession, the Law Foundation and other research funders have important roles to play in all of this. If there is a weakness in the contemporary picture it is that the historian's side of the ledger is far better represented than the lawyer's side. Outside the efforts of Wilbur Bowker, Janice Dickin McGinnis and Peter Sibenik, much of the effort has come from the ranks of the historians. There have, it is true, been useful individual contributions by a small number of legal scholars. ${ }^{62}$ However, there is lacking an individual or group committed to writing in the field. This is unlike the situation in several other provinces where law teachers are in the forefront of legal historical scholarship. The two Alberta law schools might well consider how this might be remedied.

An example of the former is municipal and provincial policing. Women's legal history and legal culture and ideology represent two areas in which some work has already been done that awaits further enrichment.

60 A good example of recent work in Canada of this type which is informed by feminist legal theory is C. Backhouse, Petticoats and Prejudice: Women and the Law in Nineteenth Century Canada (Toronto: Women's Press, 1991). 
Challenges which lie ahead include the important one of expanding interest in the legal history of the country and region, both within the legal community and the community at large. There is no good reason why the Canadian legal historical record, like any other part of our history, should be only the preserve of academics. Indeed, there are strong arguments that an appreciation of constitutional and legal history is important to reasoned discussion on a wide range of contemporary public policy issues. One way to achieve this objective is to encourage the recording and preservation of writing on legal history which is aimed at non-specialist constituencies. Work has already been done in this field in Alberta which is valuable and suggestive. Rod Macleod has made contributions to the widening of historical horizons through his work on the Social Studies Curriculum in Alberta schools and entries in general encyclopedias. ${ }^{63}$ Furthermore, the Calgary Bar Association has worked for a number of years on recording the history of Bench and Bar in Southern Alberta on tape and in hard copy. ${ }^{64}$

In North America there are even more ambitious projects underway for disseminating the legal historical record among the legal profession and community at large. I have already mentioned the sterling work of the Osgoode Society in fostering legal historical research and writing. Some of the work published under its auspices clearly is aimed at a broader audience, including those with non-academic interests looking for information and, dare I say it, entertainment. In the United States, legal historical societies have been engaged in a range of activities designed to make the record more accessible to both the legal profession and the general public, through publications, displays, museum and heritage projects. ${ }^{65}$ In terms of reaching the public, a particularly welcome development are campaigns in both countries to preserve historic court houses and to use them to display legal artifacts and even to simulate historic trials and episodes in the law. ${ }^{66}$ It is encouraging to learn that as part of the Legal Archives Program in Alberta there is a permanent exhibit on the history of federal courts in the Court of Appeal in Calgary, and episodic displays of legal historical material elsewhere. It is to be hoped that the next twenty-five years of legal historical endeavour in the Province will involve both an enrichment of the fine scholarly record already established, and at the same time draw Canadian legal culture more clearly into the public consciousness.

Macleod consulted on the Social Studies Curriculum during the late 1970s and has written on history teaching in the school system - see "History in Canadian Secondary Schools" (1982) Can. Hist. Rev. 573. He has also contributed items to both the World Book Encyclopedia and the Canadian Encyclopedia.

is In addition to an ongoing oral history project, the Association, with the financial assistance of the Alberta Law Foundation, has published a popular history of the Southern Alberta legal profession see J. Gray, Talk to My Lawyer! Great Stories of Southern Alberta's Bar and Bench (Edmonton: Hurtig, 1987). For another worthwhile example of popular legal history, see G. Baldwin, Frontier Justice: The Reminiscences of Ged Baldwin (Edmonton: University of Alberta Press, 1987).

A particularly good example is the Ninth Judicial Circuit Historical Society based in Portland, Oregon. It includes within its current projects a journal, Western Legal History, how-to-do-it guides to oral history collection and law firm histories, an educational video on the history of law and federal courts in the American West, a narrated and illustrated history in slide form of the U.S. Court of Appeals for the Ninth Circuit, a travelling Federal courthouse exhibit and an extensive oral history project.

66 A good Canadian illustration is the Old Essex County Court House Project in Windsor, Ontario in which the building has been refurbished with courtroom space for reenactments and a museum display covering the legal history of Southwest Ontario. 